\title{
Hubungan Ilmu Negara Dengan Mata \\ Kuliah Lainnya di Fakultas Hukum
}

\author{
Nama: Tedy Fermansyah \\ Email:tedyfermansyah123@gmail.com \\ No BP : 2010003600147 \\ FAKULTAS HUKUM UNIVERSITAS \\ EKA SAKTI
}

2021

\section{A. PENDAHULUAN}

Ilmu tidak dapat dipisah-pisahkan dalam kotak- kotak yang terpaku mati(compartmentization). Oleh karena itu tidak mungkin ilmu tersebut berdiri sendiri terpisah satu samalainnya tanpa adanya pengaruh dan hubungan. Dan dalam hal ini ilmu negarasebagai salah satu cabang ilmu pengetahuan sosial sebagaimana halnya denganilmu politik, hukum, kebudayaan, ekonomi, psikologis, dan lain sebagainyamerupakan cabang dari ilmu pengetahuan sosial yang khusus.Semua ilmu-ilmu sosial khusus ini secara bersama-sama akan membentuk suatuilmu sosial ilmu umum yang akan tersalur ke dalam ilmu induknya atau mater scientarium.

Oleh karena itu ilmu negara sebagai salah satu cabang ilmu pengetahuan sosial umumnya harus bekerja sama dengan cabang-cabang ilmu pengetahuan sosial lainnya karena dapat memberi dan menerima pengaruhnya dan bantuan jasanyasatu sama lain yang saling memerlukan sehingga dapat saling mengisi dan lengkap melengkapi, sehingga terwujud hubungan komplementer. Karenanya akan lebih bermanfaat bila memahami objek yang diselidikinyapun terdapat hubungan secara interdependen di antara cabang-cabang ilmu pengetahuan sosial itu dengan yang lainnya, dikarenakan mempergunakan metodedan teknik yang sama.

Metode dan teknik ilmu pengetahuan sosial pada umumnya dipergunakan pula oleh hampir semua cabang-cabang ilmu pengetahuan sosial pada khususnya, seperti ilmu negara, ilmu hukum, ilmu politik dan lainsebagainya.Dalam hubungan secara khusus antara ilmu negara dengan cabang-cabang ilmu pengetahuan sosial tertentu, dimaksudkan adanya hubungan yang pada pokoknya dititik beratkan dan digolongkan kepada objek penyelidikan yang sama yaitu;negara. Hal ini terutama nampak dengan jelas hubungan khusus antara ilmu negaradengan ilmu politik, ilmu hukum tata negara dalam arti luas dan ilmu perbandingan hukum tata negara.

\section{B. PEMBAHASAN}




\section{Hubungan secara Umum}

Ilmu tidak dapat dipisah-pisahkan dalam kotak-kota yang terpaku mati. Oleh karena itu, tidak mungkin ilmu tersebut berdiri sendiri terpisah satu sama lainnya tanpa adanya pengaruh dan hubungaan. Dalam hal ini, ilmu negara sebagai salah satu cabang dari ilmu pengetahuan sosial sebagaimana halnya dengan ilmu hokum, politik, ekonomi, kebudayaan,psikologi,dan lain sebagainya, merupakan cabang dari ilmu pengetahuan sosial yang khusus. Semua ilmu-ilmu sosial khusus ini secara bersama-sama akan membentuk suatu ilmu sosial umum yang akan tersalur ke dalam ilmu induknya.

Oleh karena itu, ilmu negara sebagai salah satu cabang ilmu pengetahuan sosial umum, harus bekerja sama dengan cabang-cabang ilmu pengetahuan sosial lainnya, karena dapat memberi dan menerima pengaruhnya dan bantuan jasanya satu sama lain yang saling memerlukan, sehingga dapat saling mengisi dan saling melengkapi, sehingga terwujud hubungan komplementer.

\section{Hubungan Secara Khusus}

\section{Hubungan Ilmu Negara dengan Ilmu Politik}

Kalau diperhatikan pendapat Georg Jellinek dalam bukunya"ALgemeine Staatslehre", ilmu Negara sebagai theoritische staatswissenschaft atau staatslehre merupakan hasi penyelidikan dari staten kunde. Bahan-bahan tersebut di bahas, dianalisis, dan di perbandingkan satu sama lain,sehinnga terdapat persamaan-persamaan diantara berbagai sifat dari organisasi-organisasi negara itu. Ilmu negara lebih menitik beratkan kepada sifat-sifat teoretis, sehingga kurang dinamis. Hal ini berarti bahwa lebih banyak memerhatikan unsur-unsur statis dari negara yang mempunyai tugas utama untuk melengkapi dengan memberikan pengertian-pengertian pokok yang jelas. Yang mendasari konsepsi-konsepsi ilmu politik lebih menitikberatkan kepada faktor-faktor yang konkrit, terutama sekali berpusat kepada gejala-gejala kekuasaan, baik yang mengenai organisasi Negara maupun yang memengaruhi pelaksanaan tugas-tugas Negara.

Maka dalam hubungan ini jelaslah ada sifat-sifat komplementer. Karena itu, ilmu negara merupakan salah satu bardcore (teras inti) dari ilmu politik

\section{Hubungan Ilmu Negara dengan Ilmu Hukum Tata Negara dan Ilmu Hukum Administrasi negara}

Ilmu hukum tata negara dan ilmu hukum administrasi negara mempunyai hubungan yang erat dengan ilmu negara karena ilmu-ilmu tersebut mempunyai obyek 
yang sama dengan ilmu negara, yaitu negara. Perbedaannya ilmu hukum tata Negara dan ilmu hokum administrasi negara memandang negara dari sifatnya atau pengertiannya yang konkrit. Obyek dari ilmu hukum tata negara dan ilmu hokum administrasi negara adalah negara yang sudah terikat pada tempat, keadaan, dan waktu. Jadi telah mempunyai ajektif tertentu,misalnya Negara republic Indonesia. Maka dengan demikian, jelaslah bahwa ilmu negara yang merupakan ilmu pengetahuan yang menyelidiki pengertian-pengertian pokok dan sendi-sendi pokok negara dapat memberikan dasar-dasar teoretis yang bersifat umum untuk hukum tata negara. Oleh karena itu, agar dapat mengerti dengan sebaik-baiknnya dan sedalam-dalamnya system hukum ketatanegaraan dan administrasi negara sesuatu negara tertentu, sudah sewajarnyalah kita harus terlebih dahulu memiliki pengetahuan segala hal ikhwalnya secara umum tentang negara yang di dapat dalam ilmu Negara.

\section{Hubungan Ilmu Negara dengan Ilmu Perbandingan Hukum Tata Negara}

ilmu hukum perbandingan tata Negara bertugas menganalisis secara teratur, menetapkan secara sistematis, sifat-sifat apakah yang melekat padanya, sebab-sebab apa yang menimbulkannya mengubah dan menghilangkan atau menyebabkan yang satu memasuki yang lain terhadap bentuk-bentuk negara itu.

Maka dalam hubungan ini, Keranenburg menyatakan bahwa dalam menunaikan tugasnya, ilmu perbandingan hukum tata negara itu haruslah mempergunakan hasil yang diperoleh ilmu negara. Karena itu, perkembangan ilmu negara dan ilmu hukum merupakan syarat mutlak bagi kesuburan tubuhnya ilmu perbandingan hukum tata negara untuk menjadi ilmu yang member keterangan dan perbandingan.

\section{Rangkaian Hubungan antara Ilmu Negara, Ilmu Politik, Ilmu Hukum Tata Negara dan Ilmu Perbandingan Hukum Tata Negara}

Sjachran Basah mengemukakan tentang rangkaian hubungan antara ilmu negara,ilmu politik, ilmu hukum tata negara, dan ilmu perbandingan tata negara. Ilmu negara yang bersifat teoretis dan umum itu di dalam penyelidikan terhadap obyeknya lebih menitikberatkan kepada bangunan-bangunan atau lembaga-lembaga formal yang di batasi oleh hukum yang berlaku. Ilmu politik dalam penyelidikannya lebih menitikberatkan kepada gejala sosio-politik dalam masyarakat sebagai gelanggang pertarungan factor kekuasaan yang nyata, dan memperhatikan pula bagaimanakah pelaksanaan serta kegiatan-kegiatan lembaga tersebut di dalam peraktek kenyataanya, maka sifat ilmu politik itu dinamis. 
Ilmu negara, selaku bahan-bahan yang besrsifat teoretis umum, kiranya akan mendapatkan tempat sebagai bahan-bahan nyata dalm ilmu hukum tata negara dan ilmu perbandingan hukum tata negara.

Maka jelaslah, meskipun terdapat hubungan berangkai yang sangat erat antara ilmu negara, ilmu politik, ilmu hukum tata negara, dan ilmu perbandingan hukum tata negara, dan di golongkan bahwa objek sama, namun terdapat persoalan-persoalan yang di hadapi oleh ilmu-ilmu tersebut berlain-lain.

\section{C.PENUTUP}

Maka jelas meskipun terdapat hubungan berangkai yang sangat erat antara ilmu negara, ilmupolitik, ilmu hukum tata negara, dan ilmu perbandingan hukum tata negara, dan digolongkanbahwa objeknya yang sama, namun terhadap persoalan-persoalan yang dihadapi oleh ilmu-ilmu tersebut berlainan.

ilmu politik akan membatasi lapangan penyelidikannya, justru memang kepada rangka yang bersifat umum hukum, atau bahwa ilmu politik tidak akan pula merupakan suatau ilmu tentang negara-negara. Hal ini berarti mempertahankan istilah"ilmu politik" dari herman heller yang mengemukakan dengan tepat bahwa batas-batas pokok antara ilmu negara dengan ilmu politik lebih tajam dari pada perbedaannya dalan peraktek, sehingga yang pertama untuk sebagian terbesar di tuntut oleh para ahli hukum, dan yang penghabisan oleh alhi sosiologi.

Sedangkan ilmu negara dan ilmu hukum tata negara itu mempersoalkan Negara, namun ilmu hukum tata negara menyelidiki satu negara dengan system ketatanegaraannya yang tertentu, karena itu merupakan hal yang spesies, konkrit dan bersifat praktis.

\section{DAFTAR PUSTAKA}

Darmini Roza dan Laurensius Arliman S Peran Pemerintah Daerah Di Dalam Melindungi Hak Anak Di Indonesia, Masalah-Masalah Hukum, Volume 47, Nomor 1, 2018.

Laurensius Arliman S, Komnas HAM dan Perlindungan Anak Pelaku Tindak Pidana, Deepublish, Yogyakarta, 2015.

Laurensius Arliman S, Penguatan Perlindungan Anak Dari Tindakan Human Trafficking Di Daerah Perbatasan Indonesia, Jurnal Selat, Volume 4, Nomor 1, 2016.

Laurensius Arliman S, Problematika Dan Solusi Pemenuhan Perlindungan Hak Anak Sebagai Tersangka Tindak Pidana Di Satlantas Polresta Pariaman, Justicia Islamica, Volume 13, Nomor 2, 2016. 
Laurensius Arliman S, Pelaksanaan Perlindungan Anak Yang Tereksploitasi Secara Ekonomi Oleh Pemerintah Kota Padang, Veritas et Justitia, Volume 2, Nomor 1, 2016.

Laurensius Arliman S, Kedudukan Ketetapan MPR Dalam Hierarki Peraturan Perundang-Undangan Di Indonesia, Lex Jurnalica, Volume 13, Nomor 3, 2016.

Laurensius Arliman S, Komnas Perempuan Sebagai State Auxialiary Bodies Dalam Penegakan Ham Perempuan Indonesia, Justicia Islamica, Volume 14, Nomor 2, 2017.

Laurensius Arliman S, Peranan Pers Untuk Mewujudkan Perlindungan Anak Berkelanjutan Di Indonesia, Jurnal Ilmu Hukum Tambun Bungai, Volume 2, Nomor 2, 2017.

Laurensius Arliman S, Mewujudkan Penegakan Hukum Yang Baik Untuk Mewujudkan Indonesia Sebagai Negara Hukum, Jurnal Hukum Doctrinal, Volume 2, Nomor 2, 2017.

Laurensius Arliman S, Participation Non-Governmental Organization In Protecting Child Rights In The Area Of Social Conflict, The 1st Ushuluddin and Islamic Thought International Conference (Usicon), Volume 1, 2017.

Laurensius Arliman S, Partisipasi Masyarakat Dalam Pembentukan Perundang Undangan Untuk Mewujudkan Negara Kesejahteraan Indonesia, Jurnal Politik Pemerintahan Dharma Praja, Volume 10, Nomor 1, 2017, https://doi.org/10.33701/jppdp.v10i1.379.

Laurensius Arliman S, Peran Komisi Perlindungan Anak Indonesia Untuk Mewujudkan Perlindungan Anak, Jurnal Respublica Volume 17, Nomor 2, 2018.

Laurensius Arliman S, Menjerat Pelaku Penyuruh Pengrusakan Barang Milik Orang Lain Dengan Mempertimbangkan Asas Fungsi Sosial, Jurnal Gagasan Hukum, Volume 1,Nomor 1, 2019.

Laurensius Arliman S, Ilmu Perundang-Undangan Yang Baik Untuk Negara Indonesia, Deepublish, Yogyakarta, 2019.

Laurensius Arliman S, Isdal Veri, Gustiwarni, Elfitrayenti, AdeSakurawati, Yasri, Pengaruh Karakteristik Individu, Perlindungan Hak Perempuan Terhadap Kualitas Pelayanan Komnas Perempuan Dengan Kompetensi Sumber Daya Manusia Sebagai Variabel Mediasi, Jurnal Menara Ekonomi: Penelitian dan Kajian Ilmiah Bidang Ekonomi, Volume 6, Nomor 2, 2020.

Laurensius Arliman S, Pendidikan Kewarganegaraan, Deepublish, Yogyakarta, 2020.

Laurensius Arliman S, Makna Keuangan Negara Dalam Pasal Pasal 23 E Undang-Undang Dasar 1945, Jurnal Lex Librum, Volume 6, Nomor 2 Juni 2020, http://dx.doi.org/10.46839/1ljih.v6i2.151. 
Laurensius Arliman S, Kedudukan Lembaga Negara Independen Di Indonesia Untuk Mencapai Tujuan Negara Hukum, Kertha Semaya Journal Ilmu Hukum, Volume 8, Nomor 7, 2020.

Laurensius Arliman S, Pelaksanaan Assesment Oleh Polres Kepulauan Mentawai Sebagai Bentuk Pelaksanaan Rehabilitasi Bagi Pecandu Dan Korban Penyalahgunaan Narkotika, Jurnal Muhakkamah, Volume 5, Nomor 1, 2020.

Laurensius Arliman S, Aswandi Aswandi, Firgi Nurdiansyah, Laxmy Defilah, Nova Sari Yudistia, Ni Putu Eka, Viona Putri, Zakia Zakia, Ernita Arief, Prinsip, Mekanisme Dan Bentuk Pelayanan Informasi Kepada Publik Oleh Direktorat Jenderal Pajak, Volume 17, No Nomor, 2020.

Larensius Arliman S, Koordinasi PT. Pegadaian (Persero) Dengan Direktorat Reserse Narkoba Polda Sumbar Dalam Penimbangan Barang Bukti Penyalahgunaan Narkotika, UIR Law Review, Volume 4, Nomor 2, 2020, https://doi.org/10.25299/uirlrev.2020.vol4(1).3779.

Laurensius Arliman S, Tantangan Pendidikan Kewarganegaraan Pada Revolusi 4.0, Ensiklopedia Sosial Review, Volume 2, Nomor 3, 2020.

Muhammad Afif dan Laurensius Arliman S, Protection Of Children's Rights Of The Islamic And Constitutional Law Perspective Of The Republic Of Indonesia, Proceeding: Internasional Conference On Humanity, Law And Sharia (Ichlash), Volume 1, Nomor 2, 2020.

Otong Rosadi danLaurensius Arliman S, Urgensi Pengaturan Badan Pembinaan Idelogi Pancasila Berdasarkan Undang-Undang Sebagai State Auxiliary Bodies yang Merawat Pancasila dalam Perspektif Hak Asasi Manusia, Prosiding Konferensi Nasional Hak Asasi Manusia, Kebudayaan dan Tujuan Pembangunan Berkelanjutan Indonesia pada Masa Pandemi Covid-19: Tantangan untuk Keilmuan Hukum dan Sosial Volume 1, Universitas Pancasila, Jakarta, 2020. 